\title{
The Fundamental Role of Drawing as a Method of Cognition and Creative Development of Reality
}

\author{
Oleg Filippov \\ Russian State Specialized Arts Academy \\ Moscow, Russia
}

\begin{abstract}
The author of the article refers to the developmental function of drawing in historical, technical, and educational curricula. The author reviews the history of drawing, and its possibilities for the cognitional and creative development of an individual.
\end{abstract}

Keywords - image; drawing; design; space; imitation; beauty; transformation; art; creativity

\section{INTRODUCTION}

Drawing is an organic human need, helping him to survive and navigate in the modern space. Drawing is a part of the creative process. The machines cannot replace creativity. Losing the ability to draw may cause irreparable losses.

Students of Department of Art of the Russian State Specialized Arts Academy (RSSAA) start their training with the basics of drawing, as well as in all educational institutions of Russia, for admission to which students shall pass the drawing exam. Not all applicants have sufficient training due to not only the admission of people with disabilities but also to the fact that there are no specialized art schools. In the Age of Enlightenment, the French philosopher Denis Diderot wrote: "A country, in which students are taught to draw like they are taught to read and write, would surpass all other countries in all the sciences, arts, and trades" [1; P. 11]. The Russian schools devote only 1 hour per week to the art lessons, which is clearly not enough. On the other hand, Japan had apparently followed Diderot's advice and introduced daily art classes to the schools. Thus, Japan came out in the most advanced countries in the world.

\section{DRAWING AS A SOURCE OF EMOTIONAL AND INTELLECTUAL DEVELOPMENT OF AN INDIVIDUAL}

Drawing is the basis of perception and cognition of the world. All children feel the need to draw, and this is not a fancy or some talent of a kid. This is a normal cognition process: "from eye to hand". These organs' interaction helps an individual to feel complete in an environment, to navigate and construct it, to keep the records. And, therefore, to design situations, possibilities, next steps. An individual may draw a line in the sand, on stone, paper, and feel that the line can be rotated, rounded, cut and continued. He can do something new and assume what is to come; he may master space and time. By developing this quality (the ability to draw the designed), an individual develops simultaneously an enormous number of other skills and competencies, such as observation, attention, patience, the ability to compare big and small, sameness and otherness, light and dark, and so on. In this case, we do not consider color, which is a separate matter. Linear and tonal drawing led people to understand the proportions, their symmetry, rhythm, modularity - to mathematics, in other words. Careful study of nature through contemplation and imitation of the crystals, vegetable forms, living creatures' design led to geometry, botany, biology. Improvement in imitation, drawing led to the creation of the verified beauty ideals.

These assumptions are based on the centennials-old wisdom.

We begin our history, art history, anthropology and other studies with appeal to the petroglyphs, rock carvings, made before the advent of tools. There are many hypotheses on the purpose, role, and origin of these carvings. What if these are the signs that once became letters, digits, notes? Interestingly, some animals on those carvings had accurate features, while some were depicted conventionally, picturing their movements or quantities.

Honing stone tools of labor and hunting, an individual used the same inherent tools - eyes and hands, perfecting thus the brain, preparing it for the future leap in development No one can say for sure, who invented the wheel, how it moved from the world of ideas to the real world, or how necessary is the abstract idea if you have eyes and experience. The eyes record, experience is accumulated, and the hands reproduce. The hands, that are subjected to the minds and eyes, not only reproduce, but also create what was not.

\section{DRAWING AS A BASIS FOR CREATIVITY}

As before, so now, creativity starts with contemplation, observation, accumulation of impressions. But if you do not try to record your observations (at least on the sand), it is difficult to recover the seen. Writers' notebooks, artists' sketch albums, often undeciphered scientists' notes are their authors' archives. These are the parts of the creative process of exploration, understanding, and transformation of the reality. We can cite Leonardo da Vinci as an example, who made drawing into a large part of his own life. The drawing was the basis of Leonardo's artistic creativity, technical 
imagination, philosophical comprehension of life. Yet he knew it was unlikely he would be understood by his contemporaries, and therefore he had encoded his texts. Even his drawings largely remain a mystery to us, modern-day people.

Leonardo's contemporaries and close predecessors using graphical methods of study came to the idea of perspective, that moved the paintings from the linear figures to spatial ones. Easel painting first appeared.

It is impossible to overestimate what has been created by humans. Everything surrounding us in our everyday modern life was created by human eyes, hands, and minds. Modern computer technologies, also created by humans, seemingly replacing the pencil in the hand, turns out to be just another sharpened tool. It is nothing without consciousness, awareness, energy, skill.

Engaging with the youth that had arrested development for some reasons, you come to the understanding that the ability to work with pencil and paper is what helps to cover their losses. And as this young people, coming to us, have a talent for drawing, they have a pretty large opportunity to catch up with their peers and to become equal among them.

One may win an impression that the computers are almighty and they don't need people able to draw, as the machines can depict whatever is required. Let us follow a simple example. You need to make a new form of a clay (ceramic) vase, not repeating the previously existed forms. A computer keeps in its memory all the previously existed forms, sharing common features: the height, width, volume. All vases serve certain purposes: storing water, wine, oil, grain. All vases are decorated with some images, have or have not handles, lids, have textured surface, and other subtle nuances. In addition, the vases have distinctive proportions that cause human emotions. The machine doesn't have emotions. The machine can't even choose one of the several options, as it has no subjective assessment. Hence, the machine can't create something new.

Creativity is not a chess game. Creativity is irrational, unpredictable, "humane", as evidenced by the art history. The end of fine art didn't happen, despite Hegel's predictions. Painting didn't end with Malevich's black flap, although he proclaimed its end. Surely, art is going through harsh times nowadays, experiencing the competition with fine industrial technologies, but there is a breaking point visible. An individual notices the difference between hand-made work of art and surrogate, getting rid of professional enthusiasts of computers, capitalizing on aesthetically illiterate people along the way.

Of course, art sometimes takes bizarre, mysterious forms, but it always relies on the centuries-old foundation of all antique, classical, modern, and progressive traditions and schools. No one would say as Jean Auguste Dominique Ingres, that "we must not look for anything new, as everything has already been found and made; now we only need to continue to develop what there is" [2; P. 47].

\section{BETWEEN SCYLLA AND CHARYBDIS}

The process should be ongoing, continuous, and should stem from life, earth, just like the force and energy of Atlas, standing on the ground. All over the world, people have stopped following the academic scheme while teaching artists, trying to preserve the immediacy of a baby on the canvases of adults. But this is not happening. No "Dada", "Primitive" or "Naïve" art can tell the viewer anything other but what they are. At the other extreme, stemming from the denial of academic education, there is "Abstract" art, admiring itself for its plastic delights, color nuances with the complete absence of any patterns, appreciated only by a narrow circle of specialists, decorating the half-empty museums, highlighting faceless spaces of banks and offices.

Of course, this is a sign of our times, answer to the pressure of the glamorous, popular, lisp, and vulgar "art", which is more like a multi-pixel digital product, than a painting, even a poor one. "A razor-sharp image ceases to be an actual image, turning into reality - virtual reality" [3; P. 5]. It may seem that we float away from the concept of "drawing", but actually not. Aforementioned Ingres believed that painting is primarily a drawing. Picasso also believed that. In the absence of drawing, the meaning dissolves and color turns into paint.

"Painting refuses itself, parodies itself... Such painting doesn't believe in its own illusions and turns into simulation, mockery" [4; P. 4]. Perhaps, this is because art abandoned the socialization function, turning into a game.

Jean Baudrillard wrote: "The whole movement of art is diverted from the future and faces the past ... [it] borrows the forms of near or distant past, even the purely modern ones" [4; P. 5]. All the ongoing allegations and arguments, concerning the drawing, are highly relative and caused by the aggressive trends existing nowadays in Russia and other countries. Art everywhere takes inhumane forms.

These modern forms are not coming from life, nature. "... Never should anyone imitate the manner of another, as he would be called a grandson and not a son of nature concerning art" [5; P. 37].

Only by observing life, sketching characters, locations, situations, may one advance in his ability to portray life, to understand it, to be able to show life through one's skills, feelings, knowledge, experience, love to labor. "Oh, the greatest folly of those, who blame students from nature..." [5; P. 38].

Transforming, changing reality around him, an individual can't help but change himself. This is what a progress is. Over the centuries the progress has been gaining strength and grew, like a chain reaction, slowing down and recoiling in the ages of wars, revolutions, crisis, global experiments, slowing down. In these difficult times, individual switches to exaggerated projects like battering rams, armored carts, atomic bombs, hyperboloids. But in the quiet times, an individual once again returns to the process of creating beauty, as the thirst for beauty never ends. Fyodor Dostoevsky believed, that the beauty would save the world. An individual can always start again with a clean sheet and 
re-draw whatever he needs, whatever suits him, and erase whatever hinders him, incorrectly drawn. An individual may correct himself, as he has such opportunity, but we need to help him by the means of art.

Drawing passes through the entire period of education for the students of the Department of Art, both on Faculty of Art and Graphics and on Faculty of Design. Precisely the drawing performs a compensating and developing role; it also serves as a measure of not only skill, but of overall growth. Young artists learn not only to look but to see, to analyze, which is inherent to the real artists, as their purpose is to create paintings. And the paintings are the faces of age, author, his internal world. There cannot be a painting without an expressive drawing, without organized composition. But when an artist succeeds, the painting leads a long life. We may see examples of such paintings in the permanent exhibition of our Academy. The artists are our own graduates: Gogol, Tonkovskaya, Gavrin, Khadieva, etc. they succeeded.

The illustrators have it easier. They, bringing the drawing to perfection, may count on the implementation of their works in easel graphic works, books' illustrations, advertising, posters. But the illustrators are not as free in their creativity, as the artists. The designers, even more, depend on circumstances, on the whim of their customers. But even for them drawing plays a fundamental role. Once again, it all starts with a drawing "... to be able to represent easily the conceived work" [6; P. 17]. Conceived work would always be different from the works of artists and illustrators, as a piece of art can be read immediately. It can be seen at a single glance, as it is a two-dimensional image. Looking at it, an individual experiences emotional stress caused by an aesthetic component, reads the image and can determine his attitude to the work. It is still unclear, how an artist achieves this effect, but this is also a subject of interest to the painting or drawing. The drawing of a designer, architect is a complex of drawings, blueprints, showing an object, represented in three dimensions, just like a sculpture, that can be seen from all the sides. But the designer also shows the internal space. That designer's drawings do not end in themselves but illustrate the thought process. These drawings may also have their own value.

The architect Le Corbusier wrote: "By drawing, you learn to see the origin of the things. You can see, how they develop, grow, experience a metamorphosis, bloom, die. We are irrevocably committed to the "from the inside to the outside" cognition principle. Everything has a biological beginning. Biology of an aspect or a cut is as necessary as the biology of every living creature. The introduction of the term "biology" reveals the essence of research in the modern construction activities. To live, to work, to cultivate body and souls, to move - these are the actions, corresponding to the functioning of circulatory, nervous, and respiratory systems. From the inside to the outside... It all starts with a bud. You can truly appreciate and love only when by seeing the beauty on the outside, you penetrate into the heart of things by reviewing, studying, researching". "To draw means to observe, discover, invent, create" [7; P. 211].
Drawing as a base of fine arts is also an independent pictorial language, clear to all the people all over the world even without translation. As in human speech, drawing reflects an individual's process of thinking and communication. Some people are rational and objective, some are subjective, emotional, aesthetic. In some cases, an artist wants to reveal engineering design, building constructions, natural phenomena; in others an artist's strives to affect the feelings, sympathy. Everyone needs an own form of expression, with own materials and tools.

The rejection of the fundamental role of drawing is open to many hazards. Namely, this rejection, due to the new computer technologies, threatens to the aforementioned principle, although the trend appeared quite some time ago. The Impressionists, in addition to the transmission of impressions, quite humane ones, tried to dissect color, making it from discrete points, which were to mix in observers' minds. This was done by Georges Seurat and Paul Signac. The Cubists Pablo Picasso and Georges Braque laid the world into large geometric shapes, painting them locally. Wassily Kandinsky left the color richness but got rid of the shape, turning his paintings into chaotic motion of zoomorphic forms. They had a lot of followers. They also argued that they go out of life. Maybe so, as they created beautiful works of art, but still we see the experience of the previous generations, introduced to their paintings subliminally. After considering carefully, the textbook works of the great masters of the past, we may witness all their findings, such as composite, plastic parts of their works. The bad thing is, they spawned the trend of withdrawal from the traditions.

This trend was described by the Spanish philosopher José Ortega y Gasset in the previous century [8]. He described seven interrelated tendencies in contemporary art:

- The tendency toward the dehumanization of art.

- The tendency to avoid living forms.

- The desire to ensure that art is only an artwork.

- The desire to understand art as just a game.

- Gravitation toward the deep irony.

- The tendency to avoid hypocrisy at any cost in this regard through mastery.

- Art, per the young artists, is certainly alien to any transcendence.

Unfortunately, he turns out to be right. Modern-day computer technologies, although he couldn't even imagine back then, fight fire with fire, and contemporary art, looking at itself and its predecessors, repeating itself, burns in that fire.

People cease to admire the beauty of the lines, man-made attempts to follow nature, transforming it. What is beautiful in nature, is mediated by a human, as Hegel thought. But nature is primary. We must start with it, not repeating it, not doing what it was or is, but rather imagining what it could be, 
"therefore about the potential probability or necessity" [9; P. 67].

\section{CONCLUSION}

So why did the thinkers of the past reflex on what art should be and thus looked forward? Nowadays everyone is trying to justify what there is, although there is nothing in reality. The king has no clothes. The future generations will have only installation art and performances left to them.

One can look forward with optimism: everything will be fine, will be back to normal, will resume to its natural course. But the traditions are being broken, skills are being wasted away, the incentives are being lost. Assessment is limited to price with no emotions visible.

\section{REFERENCES}

[1] Denis Diderot. Essay on Painting. M.: Iskusstvo, 1936.

[2] Jean Auguste Dominique Ingres. Ingres on Art. M.: The USSR Academy of Arts, 1962.

[3] Jean Baudrillard, Illusion / Disillusion Aesthetics. RoyalLib.Com, 2010-2016.

[4] Jean Baudrillard, The Plot of Art. RoyalLib.Com, 2010-2016

[5] Leonardo da Vinci. Comments on and Art. SPB, 2008.

[6] Vitruvius. Ten Books on Architecture. M.: Arkhitektura SPB, 2014.

[7] Le Corbusier. A Life. M.: Stroyizdat, 1970.

[8] José Ortega y Gasset. Aesthetics. Philosophy of Culture. M.: Iskusstvo, 1991.

[9] Aristotle. Poetics. M.: Khud. Lit., 1957. 